\title{
Hyperuricemia and Gout - Ins and Out
}

Razzak MA ${ }^{1}$, Rahman QAA ${ }^{2}$, Nasreen $F^{3}$

DOI: https:/ / doi.org/ 10.3329/ jafmc.v15i2.50845

\begin{abstract}
Gout is a condition characterized by the deposition of monosodium urate crystals in the joints or soft tissue. The four phases of gout include asymptomatic hyperuricemia, acute gouty arthritis, intercritical gout and chronic tophaceous gout. The peak incidence occurs in patients 30 to 50 years old, and the condition is much more common in men than in women. Patients with asymptomatic hyperuricemia do not require treatment, but efforts should be made to lower their urate levels by encouraging them to make changes in diet or lifestyle. Acute gout most commonly affects the first metatarsal joint of the foot, but other joints are also commonly involved. Definitive diagnosis requires joint aspiration with demonstration of birefringent crystals in the synovial fluid under a polarized light microscope. Treatment includes nonsteroidal anti-inflammatory drugs (NSAIDs), colchicine, corticosteroids and analgesics. In patients without complications, NSAID therapy is preferred.
\end{abstract}

Key-words: Hyperuricemia, Gout.

\section{Introduction}

Hyperuricemia is a condition characterized by abnormally elevated levels of serum urate (sUA), while gout, the most common form of inflammatory arthritis, arises from the subsequent deposition of urate crystals when concentrations become saturated. Gout has been defined as "a progressive metabolic disease characterized by symptomatic hyperuricemia and deposition of monosodium urate (MSU) crystals in joints and soft tissues due to an imbalance in uric acid uptake, synthesis or excretion"1. Hyperuricemia is defined as a serum urate concentration greater than $7 \mathrm{mg}$ per $\mathrm{dL}(416 \mu \mathrm{mol}$ per $\mathrm{L})$, the approximate level at which urate is supersaturated in plasma².

Although gouty arthritis characteristically occurs in patients with hyperuricemia, it is incorrect to equate hyperuricemia with clinical gout. Researchers from the Normative Aging Study followed 2,046 initially healthy men for 15 years by taking serial measurements of serum urate levels ${ }^{3}$. The five-year cumulative incidence rates of gouty arthritis were 2.0 percent for a serum urate level of $8.0 \mathrm{mg}$ per $\mathrm{dL}(475 \mu \mathrm{mol}$ per $\mathrm{L})$ or lower, 19.8 percent for urate levels from 9.0 to $10.0 \mathrm{mg}$ per dL ( 535 to $595 \mu \mathrm{mol}$ per $\mathrm{L}$ ) and 30 percent for a serum urate level higher than $10 \mathrm{mg}$ per $\mathrm{dL}$ ( $595 \mu \mathrm{mol}$ per $\mathrm{L}$ ).

Many epidemiological studies have shown that hyperuricemia and gout are associated with the development of hypertension, cardiovascular disease, chronic kidney disease and diabetes, potentially through crystal-independent modes of action ${ }^{4-9}$. Interpretaton of these st udies is confounded by the specific definition of hyperuricemia that is applied which in turn contributes to the controversy around the notion of urate having a causal role in these conditions ${ }^{10}$.

However, it is notable that EULAR (European League Against Rheumatism) now recommends that gout could be seen as a red flag for associated cardiovascular risk factors and co-morbidity, and that blood pressure, lipids and glucose be checked and treated if abnormal11. Indeed, the number of publications on gout has almost doubled from 2009 to the end of 2017 (Figure-1).

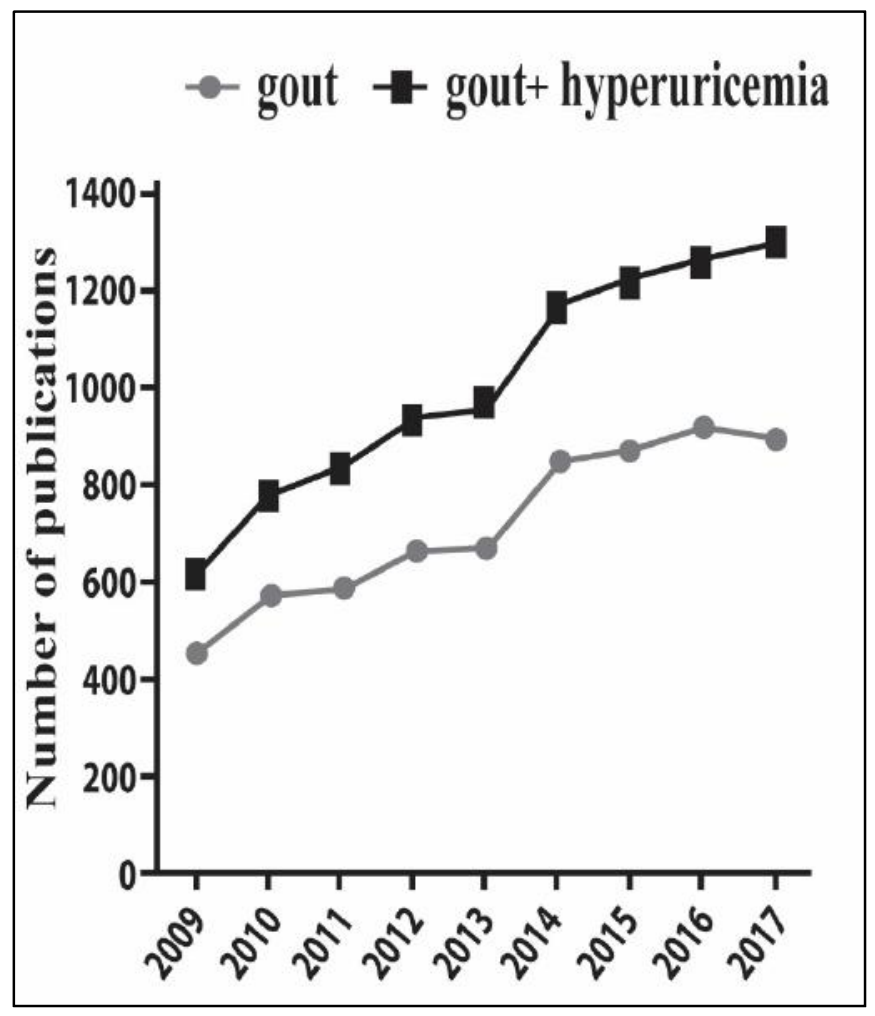

Figure-1: The Number of publications on gout and hyperuricaemia (PubMed) over past 10 years $(2018,2019 \text { not included) })^{14}$

\section{Diagnostic Criteria}

The development of the 2015 ACR-EULAR Gout Classification Criteria encompassed a multistep and data-driven process with the participation of an international group of investigators with an interest and expertise in gout comprising rheumatologists, primary care physicians, and methodologists, together with the support of the ACR and EULAR ${ }^{12,13}$ (Table-I). 
Table-I: The ACR/EULAR Gout Classification Criteria.

\begin{tabular}{|c|c|c|}
\hline Steps & Categories & Score \\
\hline $\begin{array}{l}\text { Step 1: Entry criterion (only apply criteria below to those meeting this entry } \\
\text { criterion) }\end{array}$ & $\begin{array}{l}\text { At least } 1 \text { episode of swelling, pain, or } \\
\text { tenderness in a peripheral joint or bursa }\end{array}$ & \\
\hline $\begin{array}{l}\text { Step 2: Sufficient criterion (if met, can classify as gout without applying criteria } \\
\text { below) }\end{array}$ & $\begin{array}{l}\text { Presence of MSU crystals in a symptomatic } \\
\text { joint or bursa (i.e., in synovial fluid) or tophus }\end{array}$ & \\
\hline \multicolumn{3}{|l|}{ Step 3: Criteria (to be used if sufficient criterion not met) } \\
\hline \multicolumn{3}{|l|}{ Clinical } \\
\hline \multirow[t]{2}{*}{ Pattern of joint/bursa involvement during symptomatic episode(s) evera } & $\begin{array}{l}\text { Ankle or mid-foot (as part of monoarticular or } \\
\text { oligoarticular episode without involvement of } \\
\text { the first metatarsophalangeal joint) }\end{array}$ & 1 \\
\hline & $\begin{array}{l}\text { Involvement of the first metatarsophalangeal } \\
\text { joint (as part of monoarticular or oligoarticular } \\
\text { episode) }\end{array}$ & 2 \\
\hline \multicolumn{3}{|l|}{ Characteristics of symptomatic episode(s) ever } \\
\hline $\begin{array}{l}\text { - Erythema overlying affected joint (patient-reported or physician- } \\
\text { observed) }\end{array}$ & One characteristic & 1 \\
\hline - Can't bear touch or pressure to affected joint & Two characteristics & 2 \\
\hline - Great difficulty with walking or inability to use affected joint & Three characteristics & 3 \\
\hline \multicolumn{3}{|l|}{ Time course of episode(s) ever } \\
\hline \multicolumn{3}{|l|}{ Presence (ever) of $\geq 2$, irrespective of anti-inflammatory treatment: } \\
\hline - Time to maximal pain $<24$ hours & One typical episode & 1 \\
\hline - Resolution of symptoms in $\leq 14$ days & Recurrent typical episodes & 2 \\
\hline \multicolumn{3}{|l|}{$\begin{array}{l}\text { - Complete resolution (to baseline level) between symptomatic } \\
\text { episodes }\end{array}$} \\
\hline \multicolumn{3}{|l|}{ Clinical evidence of tophus } \\
\hline $\begin{array}{l}\text { Draining or chalk-like subcutaneous nodule under transparent skin, often } \\
\text { with overlying vascularity, located in typical locations: joints, ears, olecranon } \\
\text { bursae, finger pads, tendons (e.g., Achilles) }\end{array}$ & Present & 4 \\
\hline \multicolumn{3}{|l|}{ Laboratory } \\
\hline \multicolumn{3}{|l|}{ Serum urate: Measured by uricase method. } \\
\hline $\begin{array}{l}\text { Ideally should be scored at a time when the patient was not receiving } \\
\text { urate-lowering treatment and it was }>4 \text { weeks from the start of an episode (i.e., } \\
\text { during intercritical period); if practicable, retest under those conditions. The } \\
\text { highest value irrespective of timing should be scored. }\end{array}$ & 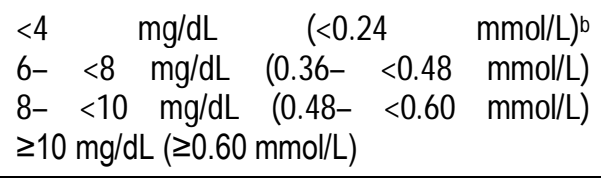 & $\begin{array}{l}-4 \\
2 \\
3 \\
4\end{array}$ \\
\hline $\begin{array}{l}\text { Synovial fluid analysis of a symptomatic (ever) joint or bursa (should be } \\
\text { assessed by a trained observer)c }\end{array}$ & MSU negative & -2 \\
\hline \multicolumn{3}{|l|}{ Imaging } \\
\hline $\begin{array}{l}\text { Imaging evidence of urate deposition in symptomatic (ever) joint or bursa: } \\
\text { ultrasound evidence of double-contour signd or DECT demonstrating } \\
\text { uratedepositione }\end{array}$ & Present (either modality) & 4 \\
\hline $\begin{array}{l}\text { Imaging evidence of gout-related joint damage: conventional radiography } \\
\text { of the hands and/or feet demonstrates at least } 1 \text { erosion }\end{array}$ & Present & 4 \\
\hline
\end{tabular}

A web-based calculator can be accessed at: http:// goutclassification calculator.auckland.ac.nz, and through the American College of Rheumatology (ACR) and European League Against Rheumatism (EULAR) web sites. ${ }^{12,13}$ Reprinted by permission of Arthritis \&
Rheumatology/John Wiley and Sons and Annals of the Rheumatic Diseases/BMJ.

aSymptomatic episodes are periods of symptoms that include any swelling, pain, and/or tenderness in a peripheral joint or bursa 
blf serum urate level is $<4 \mathrm{mg} / \mathrm{dL}(<0.24 \mathrm{mmo} / / \mathrm{liter})$, subtract 4 points; if serum urate level is $\geq 4-<6 \mathrm{mg} / \mathrm{dL}(\geq 0.24-<0.36 \mathrm{mmol} / \mathrm{L})$, score this item as 0

clf polarizing microscopy of synovial fluid from a symptomatic (ever) joint or bursa by a trained examiner fails to show monosodium urate monohydrate (MSU) crystals, subtract 2 points. If synovial fluid was not assessed, score this item as 0 . If imaging is not available, score these items as 0

dHyperechoic irregular enhancement over the surface of the hyaline cartilage that is independent of the insonation angle of the ultrasound beam (note: false-positive double-contour sign (artifact) may appear at the cartilage surface but should disappear with a change in the insonation angle of the probe)

ePresence of color-coded urate at articular or periarticular sites. Images should be acquired using a dual-energy computed tomography (DECT) scanner, with data acquired at 80 and $140 \mathrm{kV}$ and analyzed using gout-specific software with a two-material decomposition algorithm that color-codes urate. A positive scan is defined as the presence of color-coded urate at articular or periarticular sites. Nailbed, submillimeter, skin, motion, beam hardening, and vascular artifacts should not be interpreted as DECT evidence of urate deposition

tErosion is defined as a cortical break with sclerotic margin and overhanging edge, excluding distal interphalangeal joints and gull wing appearance

\section{Pathophysiology}

Uric acid (2,6,8 trioxypurine-C5H4N4O3) is the result of purine breakdown. At the normal physiological $\mathrm{pH}$ of 7.4 , uric acid circulates in the ionized form of urate. Purine metabolism mainly occurs in the liver, but it can also be produced in any other tissue that contains xanthine oxidase (intestines). About two-thirds of uric acid is excreted in the kidneys, and a third is excreted into the intestine. In the kidneys, it is filtered and secreted, and $90 \%$ is reabsorbed. Other mammals have lower uric acid levels due to the activity of uricase. This enzyme converts urate to the more water soluble form of allantoin'15 (Figure-2) (Figure-3).

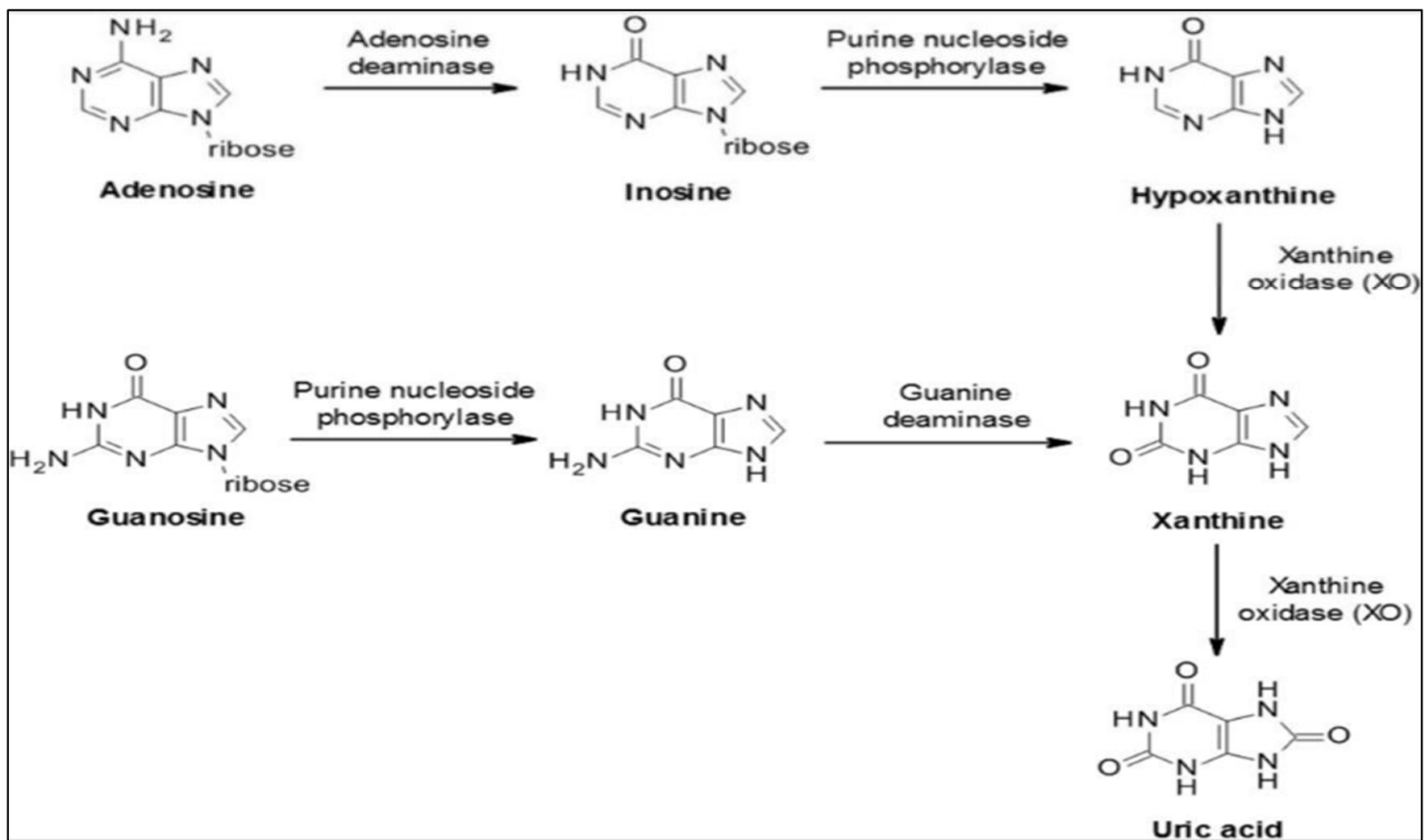

Figure-2: Biosynthesis of uric acid from purines. Purine mononucleotides are catabolized to produce uric acid although the underlying pathway can vary in different tissues and cells. A schematic example pathway is shown ${ }^{16}$.

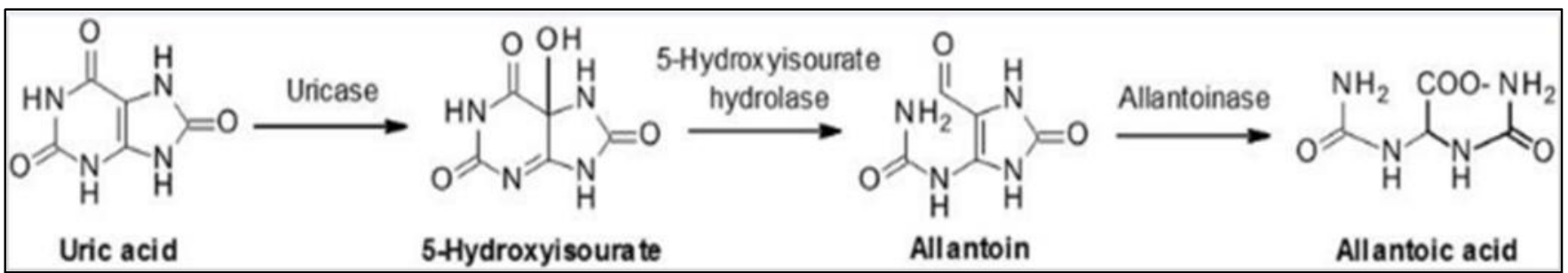

Figure-3: Uric acid Metabolism via uricase ${ }^{16}$

\section{Etiology}


Hyperuricemia predisposes patients to both gout and nephrolithiasis, but therapy is generally not warranted in the asymptomatic patient. Recognizing hyperuricemia in the asymptomatic patient, however, provides the physician with an opportunity to modify or correct underlying acquired causes of hyperuricemia ${ }^{18}$ (Table-II).

Table-II: Acquired Causes of Hyperuricemia

\begin{tabular}{|c|c|}
\hline \multicolumn{2}{|c|}{ Increased urate production } \\
\hline \multicolumn{2}{|l|}{ Cause } \\
\hline Nutritional & $\begin{array}{l}\text { Excess purine, ethanol, fructose } \\
\text { consumption }\end{array}$ \\
\hline Hematologic & $\begin{array}{l}\text { Myeloproliferative and } \\
\text { lymphoproliferative disorders, } \\
\text { polycythemia }\end{array}$ \\
\hline Drugs & $\begin{array}{l}\text { Ethanol, cytotoxic drugs, vitamin } \\
\text { B12 (treatment of pernicious } \\
\text { anemia) }\end{array}$ \\
\hline Miscellaneous & $\begin{array}{l}\text { Obesity, psoriasis, } \\
\text { hypertriglyceridemia }\end{array}$ \\
\hline \multicolumn{2}{|c|}{$\begin{array}{l}\text { Error of purine metabolism } \\
\text { phosphoribosyl transferase (HPRT) } \\
\text { pyrophosphate (PRPP) synthetase } 0 \\
\text { Decreased renal excretion of urate }\end{array}$} \\
\hline \multicolumn{2}{|c|}{\begin{tabular}{l|l} 
Cause &
\end{tabular}} \\
\hline Drugs & $\begin{array}{l}\text { Ethanol, cyclosporine } \\
\text { (Sandimmune), thiazides, } \\
\text { furosemide (Lasix) and other loop } \\
\text { diuretics, ethambutol (Myambutol), } \\
\text { pyrazinamide, aspirin (low-dose), } \\
\text { levodopa (Larodopa), nicotinic acid } \\
\text { (Nicolar) }\end{array}$ \\
\hline Renal & $\begin{array}{l}\text { Hypertension, polycystic kidney } \\
\text { disease, chronic renal failure (any } \\
\text { etiology) }\end{array}$ \\
\hline Metabolic/endocrine & $\begin{array}{l}\text { Dehydration, lactic acidosis, ketosis, } \\
\text { hypothyroidism, } \\
\text { hyperparathyroidism }\end{array}$ \\
\hline Miscellaneous & $\begin{array}{l}\text { Obesity, sarcoidosis, toxemia of } \\
\text { pregnancy }\end{array}$ \\
\hline
\end{tabular}

\section{Clinical Features \\ Asymptomatic Hyperuricemia}

Asymptomatic hyperuricemia is the term for an abnormally high serum urate level, without gouty arthritis or nephrolithiasis. Hyperuricemia is defined as a serum urate concentration greater than $7 \mathrm{mg}$ per $\mathrm{dL}(416 \mu \mathrm{mol}$ per $\mathrm{L})$, the approximate level at which urate is supersaturated in plasma2.

\section{Acute Gout}

Acute gout is characterized by the sudden onset of pain, erythema and limited range of motion and swelling of the involved joint. Often quoted, the English physician Thomas Sydenham's classic description of his own gouty sufferings is as true today as it was in the 17th century:
"The victim goes to bed and sleeps in good health. About two o'clock in the morning he is awakened by a severe pain in the great toe; more rarely in the heel, ankle or instep. This pain is like that of dislocation. Then follows chills and shivers and a little fever. The pain, which was at first moderate, becomes more intense. So exquisite and lively meanwhile is the feeling of the part affected, that it cannot bear the weight of bedclothes nor the jar of a person walking in the room ${ }^{19}$.

The peak incidence of acute gout occurs between 30 and 50 years of age ${ }^{20}$. Approximately 90 percent of first attacks are monoarticular. In more than one half of patients with acute gout, the first metatarsophalangeal joint is the initial joint involved, a condition known as podagra (Figure-4). Joint involvement (in order of decreasing frequency) includes the metatarsophalangeal joint, the instep/forefoot, the ankle, the knee, the wrist and the fingers.

Gout in women occurs exclusively after menopause. Women develop gout at an older age than men and have twice the prevalence of hypertension, renal insufficiency and exposure to diuretics ${ }^{21}$.
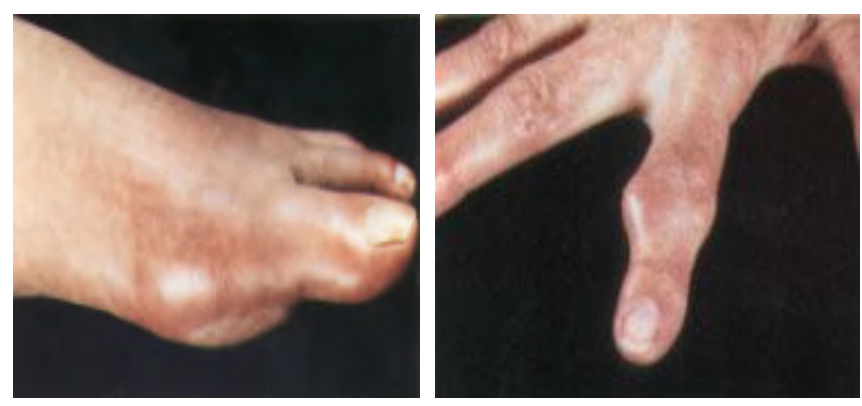

Figure-4: Acute gout. Note erythema and swelling of the first metatarsophalangeal joint and gouty tophi involving the proximal interphalangeal joint with erythema of the overlying skin ${ }^{18}$.

\section{Recurrent Gouty Arthritis}

Approximately 60 percent of patients have a second attack within the first year, and 78 percent have a second attack within two years. Polyarticular involvement also becomes more common over time and can often mimic other forms of arthritis. Gouty arthritis may mimic rheumatoid arthritis, with symmetric small-joint involvement and tophaceous deposits on extensor tendon surfaces that resemble rheumatoid nodules. As many as 30 percent of patients with tophaceous gout also have low titers of rheumatoid factor, adding to the diagnostic confusion22.

\section{Chronic Tophaceous Gout}

Tophi are chalky deposits of sodium urate that are large enough to be seen on radiographs and may occur at virtually any site. The most common sites include the joints of the hands or feet. The helix of the ear, the olecranon bursa and the Achilles tendon are classic, albeit less common, locations for tophi. Articular tophaceous gout can result in a destructive arthropathy and chronic secondary osteoarthritis. The duration of time between the first gouty attack and recognizable tophaceous disease is highly variable and may range from three to 42 years (mean: 11.6 years) ${ }^{23}$. Tophaceous disease is more likely to occur in patients with the following: A poly-articular presentation, a serum urate level higher than $9.0 \mathrm{mg}$ per dL (535 $\mu \mathrm{mol}$ per $\mathrm{L}$ ) and a younger age at disease onset (i.e., 40.5 years or younger) ${ }^{24}$. 


\section{Associated Comorbidities}

\section{Cardiovascular Disease}

Over the last decade, we have seen an accumulating body of evidence which implicates gout and/or uric acid elevation as an independent predictor for hypertension, atrial fibrillation and cardiovascular disease $25-30$. Clinical observations showing an association between high uric acid levels and hypertension are further corroborated in the pediatric and adolescent populations where blood pressure values are significantly elevated (>95th percentile) in the presence of sUA levels of $>5.5 \mathrm{mg} / \mathrm{dL}^{31-33}$. Furthermore, independently of the pharmacological mechanism (both $\mathrm{XO}$ inhibitor and uricosuric), reduction of SUA has been shown to lower blood pressure in early primary hypertension in adolescents ${ }^{32}$.

\section{Kidney Disease}

It is well accepted that hyperuricemia is associated with crystalrelated pathologies such as nephrolithiasis. High plasma urate levels are associated with an increased risk of acute kidney injury34,35. Studies further suggest potential for renal injury in a manner analogous to cardiovascular outcomes due to renal vasoconstriction via inflammation, endothelial dysfunction and renin-antiotensin system activation ${ }^{36,37}$.

\section{Type 2 Diabetes}

In population-based studies, hyperuricemia was shown to be an independent risk factor for developing Type 2 diabetes (T2D). In cardiovascular disease, there is a complex interplay of factors with obesity, insulin resistance and diuretic use all being associated with increased urate reabsorption confounding efforts to determine the relationship between sUA levels, kidney function and diabetes, in addition to other common co-morbidities or complications such as peripheral neuropathy38,39,40.

\section{Investigation}

- Lab studies will most likely reveal the following:

- Serum uric acid: normal is less than $6.8 \mathrm{mg} / \mathrm{dL}$

- Twenty-four--hour urine uric acid collection should be less than $600 \mathrm{mg} /$ day for an adult male on a purine free diet. A level above this implies elevated uric acid production.

- Consider complete blood count (CBC), CRP, serum creatinine, $\mathrm{CMP}$, lipid profile, calcium and phosphate levels. These laboratory studies are to assess for underlying disease leading to elevated uric acid but are adjunct studies.

- Consider joint x-rays to evaluate joint swelling; however, $x$-rays are not necessary for the diagnosis of gout.

- Renal ultrasounds are indicated in patients with uric acid nephrolithiasis.

- Consider joint aspiration to evaluate for uric acid crystals, look for negatively birefringent under polarized microscopy.

Routine screening for hyperuricemia is not recommended ${ }^{41}$.

\section{Management}

The three general goals of therapy in the management of gout are to terminate the acute painful attack, prevent recurrences and prevent or reverse the complications of urate deposition in joints, kidneys or other involved sites. There is no indication for screening asymptomatic patients for hyperuricemia. Urate-lowering drugs should not be used to treat patients with asymptomatic hyperuricemia. If hyperuricemia is identified, associated factors such as obesity, hypercholesterolemia, alcohol consumption and hypertension should be addressed ${ }^{18}$.

\section{Lifestyle and Diet}

Over the last decade, the role of diet in gout has received a strong attention by the scientific community. It has been clear that diet is partially responsible of sUAlevel fluctuations in the blood and patients with gout are recommended to reduce foods that cause an increase of sUA such as high purinerich foods, alcoholic and sweetened beverages ${ }^{42}$.

Table-III: Drugs Used in the Management of Acute Gout

\begin{tabular}{|c|c|c|}
\hline DRUG & DOSAGE & SIDE EFFECTS/COMMENTS \\
\hline NSAIDS (selected) & & \multirow{5}{*}{$\begin{array}{l}\text { Contraindicated in patients with peptic ulcer disease or systemic } \\
\text { anticoagulation; side effects include gastropathy, nephropathy, liver } \\
\text { dysfunction, central nervous system dysfunction and reversible platelet } \\
\text { dysfunction; may cause fluid overload in patients with congestive heart } \\
\text { failure }\end{array}$} \\
\hline $\begin{array}{l}\text { Indomethacin } \\
\text { (Indocin) }\end{array}$ & 25 to $50 \mathrm{mg}$ four times daily & \\
\hline $\begin{array}{l}\text { Naproxen } \\
\text { (Naprosyn) }\end{array}$ & 500 mg two times daily & \\
\hline Ibuprofen (Motrin) & $800 \mathrm{mg}$ four times daily & \\
\hline Sulindac (Clinoril) & $200 \mathrm{mg}$ two times daily & \\
\hline
\end{tabular}




\begin{tabular}{|c|c|c|}
\hline DRUG & DOSAGE & SIDE EFFECTS/COMMENTS \\
\hline Ketoprofen (Orudis) & $75 \mathrm{mg}$ four times daily & \\
\hline Colchicine & $\begin{array}{l}0.5 \text { to } 0.6 \mathrm{mg} \text { orally every hour } \\
\text { until relief or side effects occur, or } \\
\text { until a maximum dosage of } 6 \mathrm{mg} \\
\text { is reached }\end{array}$ & $\begin{array}{l}\text { Dose-dependent gastrointestinal side effects; improper intravenous } \\
\text { dosing has caused bone marrow suppression, renal failure and death (see } \\
\text { text) }\end{array}$ \\
\hline \multicolumn{3}{|l|}{ Corticosteroids } \\
\hline Oral & $\begin{array}{l}\text { Prednisone, } 0.5 \mathrm{mg} \text { per } \mathrm{kg} \text { on day } \\
1 \text {, taper by } 5.0 \mathrm{mg} \text { each day } \\
\text { thereafter }\end{array}$ & Fluid retention; impaired wound healing \\
\hline Intramuscular & $\begin{array}{l}\text { Triamcinolone acetonide } \\
(\text { Kenalog), } 60 \text { mg intramuscularly, } \\
\text { repeat in } 24 \text { hours if necessary }\end{array}$ & May require repeat injections; risk of soft tissue atrophy \\
\hline \multirow{2}{*}{ Intra-articular } & Large joints: 10 to $40 \mathrm{mg}^{*}$ & \multirow{2}{*}{ Preferable route for monoarticular involvement } \\
\hline & Small joints: 5 to $20 \mathrm{mg}^{*}$ & \\
\hline $\mathrm{ACTH} \dagger$ & $\begin{array}{l}40 \text { to } 80 \text { IU intramuscularly; } \\
\text { repeat every } 8 \text { hours as } \\
\text { necessary }\end{array}$ & $\begin{array}{l}\text { Repeat injections are commonly needed; requires intact pituitary-adrenal } \\
\text { axis; stimulation of mineralocorticoid release may cause volume overload }\end{array}$ \\
\hline
\end{tabular}

NSAIDs = nonsteroidal anti-inflammatory drugs; $\mathrm{ACTH}=$ adrenocorticotropic hormone.

*-Using triamcinolone hexacetonide (AristospanIntralesional), triamcinolone acetonide or methylprednisolone (Medrol).

$\dagger-$ To be administered in an inpatient setting only.

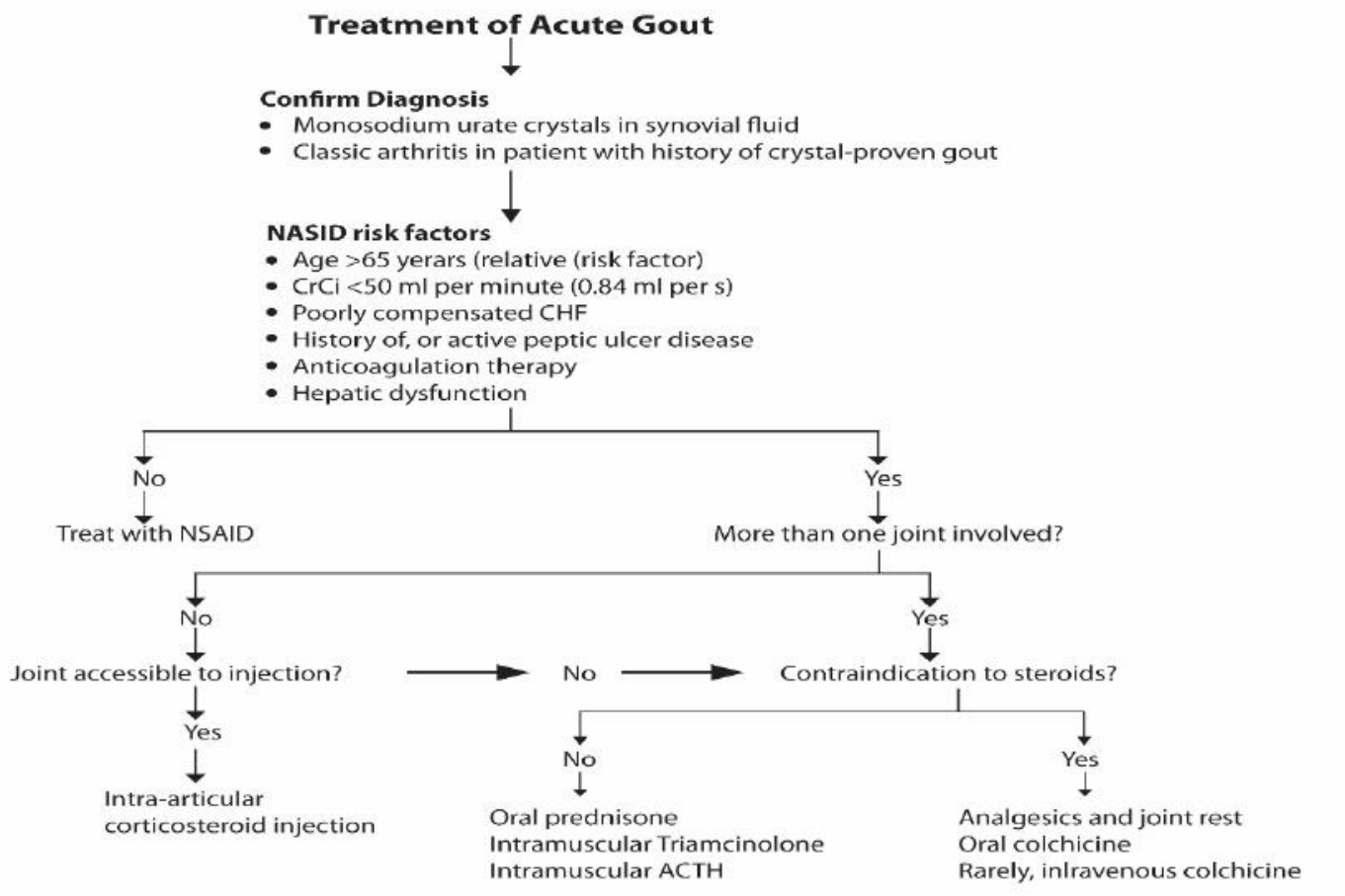

Figure-5: Treatment of Acute Gout ${ }^{18}$ 


\section{Urate-lowering medications:}

- Allopurinol: xanthine oxidase inhibitors; used as prophylaxis against gouty arthritis, nephrolithiasis, and chemo related hyperuricemia.

- Probenecid: inhibits URAT1 result in increased uric acid secretion and used as second-line therapy for gout.

- Rasburicase: recombinant uricase that converts uric acid to allantoin which is much more water soluble and readily excreted from the kidneys and used as prophylaxis against chemo-related hyperuricemia ${ }^{41}$.

\section{Conclusion}

Hyperuricemia and gout are best managed by a multidisciplinary team that includes an internist, primary care provider, nurse practitioner, endocrinologist, a rheumatologist. Already known to ancient Egyptians, gout is one of the first diseases which have been described as a clinical entity. To date, gout is the most common form of inflammatory arthritis. The increasing incidence of risk factors such as hypertension, obesity, and renal failure together with an ever-growing life expectancy has led in recent decades to a significant increase in gout prevalence.This article addresses the issue of gout by highlighting the role played by the kidneys in uric acid homeostasis; the clinical effect of crystal deposition in tissues, including the kidney; the more recent guidelines on diagnosis and management strategies, with special regard to the use of old and new drugs in renal patients.

\section{References}

1. Brook RA, Forsythe A, Smeeding JE et al. Chronic gout: Epidemiology, disease progression, treatment and disease burden. Curr Med Res Opin 2010; 26:2813-21.

2. Loeb $\mathrm{JN}$. The influence of temperature on the solubility of monosodium urate. Arthritis Rheum 1972; 15:189-92.

3. Campion EW, Glynn RJ, DeLabry LO. Asymptomatic hyperuricemia. Risks and consequences in the Normative Aging Study. Am J Med 1987; 82:421-6.

4. Kim SY, Guevara JP, Kim KM et al. Hyperuricemia and risk of stroke: A systematic review and meta-analysis. Arthritis Rheum 2009; 61:885-92.

5. Kim SY, Guevara JP, Kim KM et al. Hyperuricemia and coronary heart disease: a systematic review and meta-analysis. Arthritis Care Res 2010; 62:170-80.

6. Li L, Yang $C$, Zhao $Y$ et al. Is hyperuricemia an independent risk factor for new-onset chronic kidney disease? A systematic review and meta-analysis based on observational cohort studies. BMC Nephrol 2014; 15:122.

7. Li M, Hou W, Zhang $X$ et al. Hyperuricemia and risk of stroke: A systematic review and meta-analysis of prospective studies. Atherosclerosis 2014; 232:265-70.

8. Wang J, Qin T, Chen J et al. Hyperuricemia and risk of incident hypertension: a systematic review and meta-analysis of observational studies. PLoS ONE 2014; 9:e114259

9. Kim S, Chang Y, Yun KE et al. Development of nephrolithiasis in asymptomatic hyperuricemia: A cohort study. Am J Kidney Dis 2017; 70:173-81.
10. Stamp L, Dalbeth N. Urate-lowering therapy for asymptomatic hyperuricaemia: A need for caution. Semin Arthritis Rheum 2017; 46:457-64.

11. Richette P, Doherty M, Pascual E et al. 2016 updated EULAR evidence-based recommendations for the management of gout. Ann Rheum Dis 2017; 76:29-42.

12. Neogi $\mathrm{T}$, Jansen $\mathrm{TL}$, Dalbeth $\mathrm{N}$ et al. Gout Classification Criteria: An American College of Rheumatology/European League against Rheumatism collaborative initiative. Arthritis Rheumatol 2015; 67(10):2557-68.

13. Neogi $T$, Jansen TL, Dalbeth $N$ et al. Gout classification criteria: an American College of Rheumatology/European League Against Rheumatism collaborative initiative. Ann Rheum Dis 2015; 74:1789-98.

14. Punzi L, Scanu A, Spinella $P$ et al. One year in review 2018 : Gout. Clin Exp Rheumatol 2019; 37(1):1-11

15. Yakupova SP. Gout: New opportunities of diagnosis and treatment. Ter Arkh 2018; 90(5):88-92.

16. Benn CL, Dua P, Gurrell R et al. Physiology of Hyperuricemia and Urate-Lowering Treatments. Front Med (Lausanne) 2018; 5:160.

17. Barkas F, Elisaf $M$, Liberopoulos $E$ et al. Uric acid and incident chronic kidney disease in dyslipidemic individuals. Curr Med Res Opin 2018; 34(7):1193-9.

18. Harris MD, Siegel LB, Alloway JA. Gout and Hyperuricemia. Am Fam Physician 1999; 59(4):925-34.

19. Kelley W, Schumacher HR. Crystal-associated Synovitis: Gout. In: Kelley WN, ed. Textbook of rheumatology. 4th ed. Philadelphia: Saunders, 1993:1291-336.

20. Grahame R, Scott JT. Clinical survey of 354 patients with gout. Ann Rheum Dis 1970; 29:461-8.

21. Puig JG, Michan $A D$, Jimenez $M L$ et al. Female gout. Clinical spectrum and uric acid metabolism. Arch Intern Med 1991; 151:726-32.

22. Kozin F, McCarty DJ. Rheumatoid factors in the serum of gouty patients. Arthritis Rheum 1977; 20:1559-60.

23. Hench PS. The diagnosis of gout and gouty arthritis. J Lab Clin Med 1936; 220:48.

24. Nakayama DA, Barthelemy C, Carrera G et al. Tophaceous gout: A clinical and radiographic assessment. Arthritis Rheum 1984; 27:468-71.

25. Mandel NS, Mandel IC, Kolbach-Mandel AM. Accurate stone analysis: the impact on disease diagnosis and treatment. Urolithiasis 2017; 45:3-9.

26. Kuwabara M, Bjornstad $P$, Hisatome I et al. Elevated serum uric acid level predicts rapid decline in kidney function. Am J Nephrol 2017; 45:330-7.

27. Mallat SG, Al Kattar S, Tanios BY et al. Hyperuricemia, hypertension and chronic kidney disease: An emerging association. Curr Hypertens Rep 2016; 18:74.

28. Borghi $\mathrm{C}$. The role of uric acid in the development of cardiovascular disease. Curr Med Res Opin 2015; 31 (Suppl. 2):1-2.

29. Borghi $C$, Rosei EA, Bardin T et al. Serum uric acid and the risk of cardiovascular and renal disease. J Hypertens 2015; 33:1729-41; discussion 1741. 
30. Mancia G, Grassi G, Borghi C. Hyperuricemia, urate deposition and the association with hypertension. Curr Med Res Opin 2015; 31 (Suppl. 2):15-9.

31. Kawasoe S, Kubozono T, Yoshifuku S et al. Uric acid level and prevalence of atrial fibrillation in a Japanese general population of 2,85,882. Circ J 2016; 80:2453-9.

32. Alper Jr AB, Chen W, Yau L et al. Childhood uric acid predicts adult blood pressure: The Bogalusa Heart Study. Hypertension 2005; 45:34-8.

33. Feig DI. The role of uric acid in the pathogenesis of hypertension in the young. J Clin Hypertens 2012; 14:346-52.

34. Keenan T, Zhao W, Rasheed A et al. Causal assessment of serum urate levels in cardiometabolic diseases through a mendelian randomization study. J Am Coll Cardiol 2016; 67:407-16.

35. Greenberg KI, McAdams-DeMarco MA, Kottgen A et al. Plasma urate and risk of a hospital stay with AKI: The atherosclerosis risk in communities study. Clin J Am SocNephrol 2015; 10:776-83.

36. $\mathrm{Xu} \mathrm{X}, \mathrm{Hu}$ J, Song $\mathrm{N}$ et al. Hyperuricemia increases the risk of acute kidney injury: a systematic review and meta-analysis. BMC Nephrol 2017; 18:27.
37. Ejaz AA, Mu W, Kang DH et al. . Could uric acid have a role in acute renal failure? Clin J Am Soc Nephrol 2007; 2:16-21.

38. Nashar K, Fried LF. Hyperuricemia and the progression of chronic kidney disease: Is uric acid a marker or an independent risk factor? Adv Chronic Kidney Dis 2012; 19:386-91.

39. Bhole V, Choi JW, Kim SW et al. Serum uric acid levels and the risk of type 2 diabetes: A prospective study. Am J Med 2010; 123:957-61.

40. Araki S, Nishio $Y$, Araki A et al. Factors associated with progression of diabetic nephropathy in Japanese elderly patients with type 2 diabetes: Sub-analysis of the Japanese Elderly Diabetes Intervention Trial. Geriatr Gerontol Int 2012; 12 (Suppl. 1):127-33.

41. Dong $H, X u Y, Z$ Zhang $X$ et al. Visceral adiposity index is strongly associated with hyperuricemia independently of metabolic health and obesity phenotypes. Sci Rep 2017; 7(1):8822.

42. Beydoun MA, Canas JA, Fanelli-Kuczmarski MT et al. Genetic risk scores, sexand dietary factors interacts to alter serum uricacid trajectory among African-American urban adults. $\mathrm{Br} \mathrm{J}$ Nutr 2017; 117:686-97 